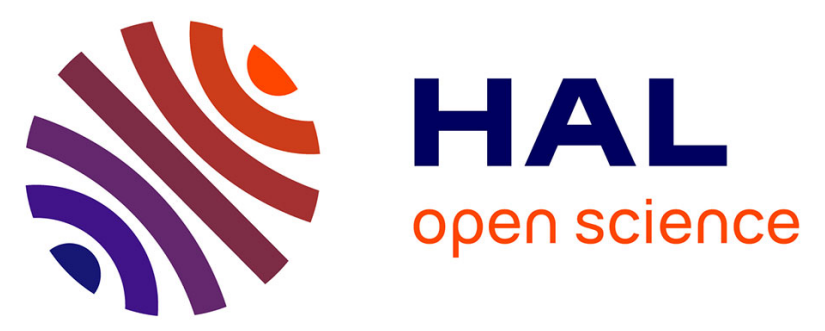

\title{
Low Prevalence of Transmitted Drug Resistance among Newly Diagnosed HIV 1 Patients in Latvia
}

Dace Balode, Maj Westman, Tatjana Kolupajeva, Baiba Rozentale, Jan Albert

\section{To cite this version:}

Dace Balode, Maj Westman, Tatjana Kolupajeva, Baiba Rozentale, Jan Albert. Low Prevalence of Transmitted Drug Resistance among Newly Diagnosed HIV 1 Patients in Latvia. Journal of Medical Virology, 2010, 82 (12), pp.2013. 10.1002/jmv.21921 . hal-00589437

\section{HAL Id: hal-00589437 https://hal.science/hal-00589437}

Submitted on 29 Apr 2011

HAL is a multi-disciplinary open access archive for the deposit and dissemination of scientific research documents, whether they are published or not. The documents may come from teaching and research institutions in France or abroad, or from public or private research centers.
L'archive ouverte pluridisciplinaire HAL, est destinée au dépôt et à la diffusion de documents scientifiques de niveau recherche, publiés ou non, émanant des établissements d'enseignement et de recherche français ou étrangers, des laboratoires publics ou privés. 


\section{Journal of Medical Virology}

WILEY

\section{Low Prevalence of Transmitted Drug Resistance among Newly Diagnosed HIV 1 Patients in Latvia}

\begin{tabular}{|c|c|}
\hline Journal: & Journal of Medical Virology \\
\hline Manuscript ID: & JMV-10-1938.R1 \\
\hline Wiley - Manuscript type: & Research Article \\
\hline $\begin{array}{l}\text { Date Submitted by the } \\
\text { Author: }\end{array}$ & 07-Jul-2010 \\
\hline Complete List of Authors: & $\begin{array}{l}\text { Balode, Dace; Swedish Institute for Infectious Disease Control, } \\
\text { Department of Virology; Karolinska Institute, Department of } \\
\text { Microbiology, Tumor and Cell Biology } \\
\text { Westman, Maj; Swedish Institute for Infectious Disease Control, } \\
\text { Department of Virology; Rigshospitalet, Copenhagen University } \\
\text { Hospital, Department of Clinical Genetics, Hematology/Oncology } \\
\text { Section } 4052 \\
\text { Kolupajeva, Tatjana; Infectology Center of Latvia, Department of } \\
\text { HIV/AIDS Diagnostics } \\
\text { Rozentale, Baiba; Infectology Center of Latvia } \\
\text { Albert, Jan; Swedish Institute for Infectious Disease Control, } \\
\text { Department of Virology; Karolinska Institute, Department of } \\
\text { Microbiology, Tumor and Cell Biology }\end{array}$ \\
\hline Keywords: & $\begin{array}{l}\text { HIV-1, Latvia, drug resistance mutations, primary resistance, } \\
\text { transmitted drug resistance }\end{array}$ \\
\hline
\end{tabular}

\section{S) ScholaroNE \\ Manuscript Central}




\section{Diagnosed HIV-1 Patients in Latvia}

3

4 Dace Balode $^{1,2, *}$, Maj Westman ${ }^{1, \dagger}$, Tatjana Kolupajeva ${ }^{3}$, Baiba Rozentale ${ }^{3,}$ Jan Albert ${ }^{1,2}$ 5

6

$7{ }^{1}$ Department of Virology, Swedish Institute for Infectious Disease Control, SE-171 82 Solna,

8 Sweden

$9{ }^{2}$ Department of Microbiology, Tumor and Cell Biology, Karolinska Institute, SE-171 77, 10 Stockholm, Sweden

$11{ }^{3}$ Infectology Center of Latvia, LV-I006, Riga, Latvia

$12 \uparrow$ Current address: Department of Clinical Genetics, Hematology/Oncology Section 4052, 13 Rigshospitalet, Copenhagen University Hospital, Copenhagen, Denmark. 14

15 *Correspondence to: Dace Balode, Department of Microbiology, Tumor and Cell Biology, 16 Karolinska Institute, SE-171 77, Stockholm, Sweden. Tel: +46 852480000

17 E-mail: dace.balode@ki.se

18 Shortened title: HIV transmitted drug resistance in Latvia. 
ABSTRACT

21 Transmitted drug resistance (TDR) is a concern because it may reduce the efficacy of 22 antiretroviral treatment. Plasma samples of 119 HIV-1 infected patients who were newly 23 diagnosed at the Infectology Center of Latvia in 2005 and 2006 were analyzed by an in-house 24 genotypic resistance assay to determine the prevalence of transmitted drug resistance in Latvia. 25 TDR was identified using the WHO 2009 list of mutations for surveillance of TDR as 26 implemented in the Stanford Calibrated Population Resistance tool. Neighbor-joining 27 phylogenetic analyses were used to determine genetic subtype and investigate the relatedness of 28 the sequences. Resistance testing was successful in 117 of 119 patients. The study population 29 represented approximately $20 \%$ of all patients that were diagnosed in Latvia in 2005 and 2006 and 30 was well distributed between gender, transmission routes and areas of residence. Four patients 31 showed evidence of TDR, which represents a prevalence of TDR of 3.4\% (95\% CI: $0.9 \%-8.5 \%$ ). 32 All four patients displayed single, but different resistance mutations (M46I, F53L, M41L, and 33 G190A). All patients, except one, were predicted to respond well to standard first-line therapy in 34 Latvia. The prevalence of TDR in Latvia was low, which partly may be due the low proportion of 35 HIV-1 patients who receive antiretroviral therapy. The results indicate that routine resistance 36 testing in Latvia currently should be focused on patients who display treatment failure, rather than 37 treatment naïve patients.

39 KEY WORDS: HIV-1, Latvia, drug resistance mutations, primary resistance, transmitted drug 40 resistance 
With the increased availability and use of antiretroviral treatment (ART) for HIV-1 infected

patients transmitted drug resistance (TDR) has become an important clinical and epidemiological problem. The reported prevalence of TDR has ranged from 0-24\% [Avi et al., 2009; Chaix et al., 2009; Little et al., 2002; Payne et al., 2008; Poggensee et al., 2007; Ross et al., 2007; Shet et al., 2006; The SPREAD programme 2008; UK Collaborative Group on HIV Drug Resistance et al., 2007; Weinstock et al., 2004; Yerly et al., 2007]. TDR represents a challenge for the control of HIV-1 infection since it can reduce the efficacy of first-line ART and thereby contribute to treatment failure [Leigh Brown et al., 2003]. The World Health Organization (WHO) recommends that countries that have installed ART programs should establish sentinel surveillance systems of TDR and make evidence-based recommendations for prevention of HIV drug resistance [Bennett et al., 2008a; Bennett et al., 2008b]. Furthermore, international treatment guidelines recommend

In Latvia, the first HIV infected patient was diagnosed in 1987. In the first ten years the epidemic evolved slowly and mainly involved infections among men who have sex with men. In 1997 an explosive outbreak of HIV-1 infections began among intravenous drug users. The outbreak culminated in 2001 when a total of 665 new infections were diagnosed among intravenous drug users. By December 2009, 4614 HIV-1 cases had been reported in Latvia. Of these 824 had developed AIDS and 486 patients had died from AIDS or other causes [Infectology Center of Latvia, 2010a]. Combination antiretroviral treatment (cART) has been available in the Latvia since 1996. Until December 2009, 990 patients had started therapy, but approximately half of these patients have either died or terminated therapy and 439 patients were reported to be under therapy at the end of 2009. The first-line regimen in Latvia usually consists of the non-nucleoside reverse transcriptase inhibitor (NNRTI) efavirenz (EFV) together with two nucleoside reverse 
66 transcriptase inhibitors (NRTIs); lamivudine (3TC) and zidovudine (AZT) or 3TC and abacavir 67 (ABC) [Infectology Center of Latvia, 2010b]. There is limited information about the prevalence of 68 TDR in Latvia, as well as in other parts of the former Soviet Union [Avi et al., 2009; Pandrea et 69 al., 2001; Rumyantseva et al., 2009; Vazquez de Parga et al., 2005]. The aim of the study was to 70 investigate prevalence of TDR in newly diagnosed treatment-naïve HIV-1 patients in Latvia. This 71 study shows that the prevalence of TDR in 2005-2006 was low, 3.4\%, which in part can be 72 explained by the low proportion of HIV-1 patients under cART. 


\section{MATERIALS AND METHODS}

74

\section{Patients}

The study included 119 Latvian HIV-1 patients who were newly diagnosed in 2005 - 2006 and from whom plasma samples frozen at $-70^{\circ} \mathrm{C}$ obtained within 180 days after diagnosis and prior to any ART were available at the Infectology Center of Latvia. The study was part of the European SPREAD (Strategy to Control SPREAD of HIV drug resistance) and EHR (EuropeHIVResistance) projects (www.europehivresistance.org). SPREAD/EHR is a multinational, multicentre surveillance program aimed to determine the prevalence of TDR in Europe. The study protocols and data collection forms from SPREAD/EHR were used. The Regional Medical Ethics Board in Stockholm, Sweden (Dnr 2008/4:1) and The Central Medical Ethics Committee in Latvia (24 march, 2005, A-4, decision nr.4) had approved the study. Written informed consent was obtained from all study subjects.

\section{Measurements of plasma HIV-1 RNA levels and CD4 cell counts}

HIV-1 RNA levels in plasma were measured using the COBAS Amplicor HIV-1 monitor version 1.5 assay (Roche Molecular Systems, Basel, Switzerland) and CD4 cell counts were measured using flow cytometry.

\section{Genotypic HIV-1 resistance testing}

Genotypic HIV-1 resistance testing was performed using a published in-house method that targets amino acids 1-99 in the protease and 1-253 in reverse transcriptase (RT) [Lindstrom and Albert, 2003; Lindström and Albert, 2003; Murillo et al., 2010]. The test has been used several years for national surveillance TDR in Sweden and has successfully undergone regular quality control within ENVA genotyping proficiency programme [Pandit et al., 2008]. 
The sequences were assembled and edited using the Sequencher ${ }^{\mathrm{TM}}$ software (Gene Codes 99 Corporation, Ann Arbor, MI, US). TDR was identified using the WHO 2009 list of mutations for 100 surveillance of TDR as implemented in the Calibrated Population Resistance tool (v5.0 beta) 101 [Bennett et al., 2009; Gifford et al., 2009] available at the Stanford HIV Drug Resistance Database 102 (hivdb.stanford.edu). The susceptibility of the viruses to antiretroviral drugs was predicted using 103 the Stanford HIVdb, ANRS and Rega algorithms as implemented in the HIValg tool also available 104 at the Stanford HIV Drug Resistance Database.

105 To determine the HIV-1 genetic subtype of the viruses, the pol sequences were manually 106 aligned with the subtype reference data set from the Los Alamos HIV Sequence Database 107 (www.hiv.lanl.gov) using the BioEdit software [Hall, 1999] and neighbor-joining (NJ) trees were 108 constructed with maximum composite likelihood substitution model using Mega v4.1 [Tamura et 109 al., 2007]. BLAST searches in the Los Alamos HIV Sequence Database were used to retrieve the 11025 most closely related database sequences to each of four samples with evidence of TDR to 111 investigate their evolutionary relationship in NJ trees. The Latvian sequences have been deposited 112 in GenBank database under accession numbers GU945072-GU945077; GU945079-GU945083; 113 GU945085-GU945092; GU945094-GU945098; GU945100-GU945102; GU945104-GU945118; 114 GU945120-GU945127 and GU945129-GU945195.

\section{Statistical analyses}

The $95 \%$ confidence interval of the prevalence of TDR was calculated using the binomial 118 distribution and the exact method. 
119

120

122

123

124

125

126

127

128

129

130

131

132

133

134

135

\section{General characteristics of the study subjects}

Genotypic resistance testing was successful for 117 of the 119 study subjects. The two patients without results from resistance testing were excluded from further analyses. The characteristics of the 117 remaining subjects are shown in Table 1 . Briefly, the reported infection route was heterosexual for $21 \%$ of the patients; intravenous drug use for $38 \%$, sex between men for $8.5 \%$ and unknown for $32.5 \%$ of the patients. Approximately $59 \%$ of the patients were males and $39 \%$ were females. The median age of the study population was 29 years (range 17-69). The median time between diagnosis and sampling for resistance testing was 6 days (range $0-166$ days). A majority of patients $(n=98 ; 84 \%)$ were infected with subtype A1 and the remaining 19 patients $(16 \%)$ were infected with subtype B. Overall we sampled around one fifth of all patients that were diagnosed in Latvia during 2005-2006 and the study subjects were well distributed between genders, transmission routes and areas of residence, but the study population included slightly lower proportions of patients from the homosexual transmission group and residents from Riga (Table 1). The age distribution of the study subjects in each transmission group did not differ from the age distribution in respective transmission groups among patients diagnosed in 2005 and 2006 (data not shown).

\section{Low prevalence of transmitted drug resistance in Latvia}

Four of the 117 study subjects displayed resistance mutations indicative of TDR according 140 to the WHO 2009 list of mutations for surveillance of transmitted drug resistance (Table 2). Thus, 141 the prevalence of TDR was low in this study population $(3.4 \%$; $95 \%$ CI: $0.9 \%-8.5 \%)$. Two of the 142 four patients with TDR had reported intravenous drug use as the route of infection, while the route 143 of infection was unknown for the other two patients. All four patients with TDR were infected 
144 with HIV-1 of subtype A1, which is the dominant subtype among HIV-1 infected intravenous

145 drug users and heterosexually infected patients in Latvia [Balode et al., 2004].

146 Each of the four patients displayed a single, but different, resistance mutation, i.e. F53L,

147 M41L, G190A and M46I, respectively (Table 2). Two of the viruses, those with M46I and F53L, 148 were predicted to be fully susceptible to standard NNRTI-based first-line cART in Latvia, despite 149 having mutations indicative of TDR. Many of the viruses $(n=36,31 \%)$ had the A62V mutation in 150 RT. All these viruses were of subtype A1. The mutation is characteristic for the subtype A1 151 variant that has spread throughout the former Soviet Union, including Latvia and is considered as 152 common natural sequence polymorphism [Sukhanova et al., 2005].

153 Phylogenetic tree analyses with Latvian and database pol sequences indicated that the four 154 patients with TDR were epidemiologically unlinked (data not shown), which was expected since 155 their viruses displayed different resistance mutations. Furthermore, the phylogenetic tree analyses 156 did not reveal any unexpected sequence similarities, which argues against the occurrence of PCR 157 contamination or sample mix-up. 
This study estimated that the prevalence of TDR was 3.4\% among Latvian HIV-1 patients diagnosed in 2005 and 2006. The estimate of TDR in Latvia agrees well with published data on 57 Latvian patients sampled in 2006-2007 and a recent conference report on 133 patients diagnosed 2006-2008, which estimated a prevalence of TDR of 7\% and 5.3\% respectively [Dusacka et al., 2009; Kolupajeva et al., 2008]. However, it is difficult to directly compare or combine the data from these studies on TDR in Latvia since there were differences in the inclusion criteria, the representativeness and the resistance algorithms used. The prevalence of TDR in Latvia was low compared to most other European countries, but there is limited data from Eastern Europe and the former Soviet Union and most published studies are small, which makes the estimates of TDR uncertain. In available reports the prevalence of TDR ranges from $0 \%$ in Estonia to $14.7 \%$ in Poland [Babic et al., 2006; Rumyantseva et al., 2009; Santoro et al., 2008; Stanczak et al., 2007; Vazquez de Parga et al., 2005].

The finding that the prevalence of TDR in Latvia was low in 2005 and 2006 is encouraging because it indicates that patients with failing therapy are not a major source of new infections. However, the low prevalence of TDR was not unexpected since the proportion of HIV-1 patients who receive therapy is relatively low in Latvia [de Joncheere et al., 2009]. Thus, approximately 570 Latvian patients had started therapy until 2006, which represent $16 \%$ of the approximately 3600 patients that had been diagnosed at this time. The data indicated that the prevalence of TDR in Latvia was below 5\% (95\% CI 0.9\%-8.5\%) in 2005 and 2006. The point estimate in report from 2006-2008 was higher, 5.3\% [Dusacka et al., 2009], but the difference is not statistically significant. Nevertheless, the recommendation by the WHO would be to review antiretroviral therapy monitoring data, investigate potential problems and repeat the survey in following year [Myatt and Bennett, 2008]. Reassuringly, the results from our study indicate that the standard 
183 first-line treatment regimen in Latvia (EFV + 3TC + AZT or ABC) would be effective in all, 184 except one, of the study subjects.

185 The fact that TDR was only observed in patients infected with subtype A1 virus was 186 somewhat surprising, because the subtype A1 epidemic in Latvia is relatively young [Balode et 187 al., 2004; Ferdats et al., 1999], which means that some patients are not yet in need of therapy. 188 Furthermore, most of the subtype A1 infections have occurred among intravenous drug users who 189 sometimes are excluded from therapy because they are considered to be at increased risk of 190 displaying poor adherence to treatment [de Joncheere et al., 2009]. Thus, one would have expected 191 that TDR would have been more common in patients infected with subtype B virus, because this 192 subtype was introduced earlier in Latvia (Balode et al, unpublished) and predominate among men 193 who have sex with men who generally have better access to ART than intravenous drug users. 194 However, it should be pointed out that this study was too small to allow reliable estimates of TDR 195 in different subgroups of patients. The phylogenetic analyses indicated that the four patients with 196 TDR were not epidemiologically linked. Thus, there were no networks of HIV drug-resistant 197 strains of the type that have been reported from other countries, such as Switzerland and Sweden 198 [Lindstrom et al., 2006; Yerly et al., 2009].

199 Some limitations of the study should be mentioned. First, the study was relatively small, 200 which makes the estimate of TDR somewhat uncertain [Marks et al., 2010], but the estimate 201 agrees quite well with two other reports from Latvia [Dusacka et al., 2009; Kolupajeva et al., 202 2008]. Second, the patients were diagnosed in 2005 and 2006 and therefore the results do not 203 necessarily reflect the current prevalence of TDR in Latvia. Third, population-based sequencing 204 does not detect minority resistance variants [Jakobsen et al., 2010], but this limitation is present 205 also in almost all other surveys of TDR. Some strengths of the study should also be mentioned. 206 Thus, the study population represented approximately $20 \%$ all patients that were diagnosed in 
208 residence. Furthermore, the results are directly comparable to data from many other European 209 countries because it was a part of the EU supported SPREAD/EHR programme [The SPREAD 210 programme 2008; Vercauteren et al., 2009].

211 Several drug resistance algorithms and mutations lists have been developed: Stanford 212 HIVdb, Rega and ANRS Algorithms and International AIDS Society (IAS) [Bennett et al., 2009; 213 Johnson et al., 2009; Liu and Shafer, 2006; Van Laethem et al., 2002]. According to a study which 214 compared Stanford HIVdb algorithm and Stanford Drug resistance mutation (SDRM) and IAS215 USA lists, the choice of genotyping definition has a minor influence on the estimated rate of TDR, 216 but have larger impact at individual level [Green et al., 2008]. In the present study we used the 217 WHO 2009 list of mutations for surveillance of TDR as implemented in the Calibrated Population 218 Resistance tool (v5.0 beta) [Gifford et al., 2009], which specifically has been developed for 219 surveillance of TDR [Bennett et al., 2008b].

220 In conclusion, this study shows that the prevalence of TDR in Latvia is low and indicates 221 that routine resistance testing should be focused on patients that display treatment failure, rather 222 than treatment naïve patients. 


\section{ACKNOWLEDGEMENTS}

225 We thank Afsaneh Heidarian for technical assistance and Dr. Diana Dusacka and Dr. 226 Ludmila Guseva for preparing the samples and epidemiological information.

227 The research leading to these results has received funding from the Swedish Research 228 Council; the Swedish Baltic Sea Grant; the Latvian Council of Science; DOE-NIH interagency 229 agreement; EU projects: SPREAD (QLK2-CT-2001-01344); EHR (LSHP-CT-2006-518211) and 230 CHAIN (FP7/2007-2013) "Collaborative HIV and Anti-HIV Drug Resistance Network" grant 231 agreement $\mathrm{n}^{\circ} 223131$. 


\section{REFERENCES}

233

234 Avi R, Huik K, Sadam M, Karki T, Krispin T, Ainsalu K, Paap P, Schmidt J, Nikitina N, Lutsar I. 2009. Absence of genotypic drug resistance and presence of several naturally occurring polymorphisms of human immunodeficiency virus-1 CRF06_cpx in treatment-naive patients in Estonia. J Med Virol 81(6):953-958.

Babic DZ, Zelnikar M, Seme K, Vandamme AM, Snoeck J, Tomazic J, Vidmar L, Karner P, Poljak M. 2006. Prevalence of antiretroviral drug resistance mutations and HIV-1 non-B subtypes in newly diagnosed drug-naive patients in Slovenia, 2000-2004. Virus Res 118(1-2):156-163.

Balode D, Ferdats A, Dievberna I, Viksna L, Rozentale B, Kolupajeva T, Konicheva V, Leitner T. 2004. Rapid epidemic spread of HIV type 1 subtype A1 among intravenous drug users in Latvia and slower spread of subtype B among other risk groups. AIDS Res Hum Retroviruses 20(2):245-249.

Bennett DE, Bertagnolio S, Sutherland D, Gilks CF. 2008a. The World Health Organization's global strategy for prevention and assessment of HIV drug resistance. Antivir Ther 13 Suppl 2:1-13.

Bennett DE, Camacho RJ, Otelea D, Kuritzkes DR, Fleury H, Kiuchi M, Heneine W, Kantor R, Jordan MR, Schapiro JM, Vandamme AM, Sandstrom P, Boucher CA, van de Vijver D, Rhee SY, Liu TF, Pillay D, Shafer RW. 2009. Drug resistance mutations for surveillance of transmitted HIV-1 drug-resistance: 2009 update. PLoS One 4(3).DOI: 10.1371/journal.pone.0004724

Bennett DE, Myatt M, Bertagnolio S, Sutherland D, Gilks CF. 2008b. Recommendations for surveillance of transmitted HIV drug resistance in countries scaling up antiretroviral treatment. Antivir Ther 13 Suppl 2:25-36. 
257 Chaix ML, Descamps D, Wirden M, Bocket L, Delaugerre C, Tamalet C, Schneider V, Izopet J, 258 Masquelier B, Rouzioux C, Meyer L, Costagliola D. 2009. Stable frequency of HIV-1 259 transmitted drug resistance in patients at the time of primary infection over 1996-2006 in $260 \quad$ France. AIDS 23(6):717-724.

261 de Joncheere K, Eramova I, Kehler J, Laukamm-Josten U, Rotberga S, Zakowicz A, Drew R. 262 2009. Evaluation of the access to HIV/AIDS treatment and care in Latvia. WHO.URL: 263 http://www.aidslex.org/site_documents/TC-0061E.pdf

264 Dusacka D, Guseva L, Kolupajeva T, Vrublevska J, Januskevica I, Vilde A, Storozenko J, 265 Rozentale B. 2009. High prevalence of polymorphism in HIV1 variants ciculating in 266 Latvia. 28-30 April, 2009; Vilnius, Lithuania. p PS2.2/1.URL: http://ec.europa.eu/eahc/documents/projects/highlights/AbstractAIDSVilnius.pdf

Ferdats A, Konicheva V, Dievberna I, Lilja E, Albert J. 1999. An HIV type 1 subtype A outbreak among injecting drug users in Latvia. AIDS Res Hum Retroviruses 15(16):1487-1490.

Gifford RJ, Liu TF, Rhee SY, Kiuchi M, Hue S, Pillay D, Shafer RW. 2009. The calibrated population resistance tool: standardized genotypic estimation of transmitted HIV-1 drug resistance. Bioinformatics 25(9):1197-1198.

Green H, Tilston P, Fearnhill E, Pillay D, Dunn DT. 2008. The impact of different definitions on the estimated rate of transmitted HIV drug resistance in the United Kingdom. J Acquir Immune Defic Syndr 49(2):196-204.

Hall TA. 1999. BioEdit: a user-friendly biological sequence alignment editor and analysisprogram for Windows 95/98/NT. Nucl Acids Symp Ser 41:95-98.

Hirsch MS, Gunthard HF, Schapiro JM, Brun-Vezinet F, Clotet B, Hammer SM, Johnson VA, Kuritzkes DR, Mellors JW, Pillay D, Yeni PG, Jacobsen DM, Richman DD. 2008. Antiretroviral drug resistance testing in adult HIV-1 infection: 2008 recommendations of an International AIDS Society-USA panel. Clin Infect Dis 47(2):266-285. 
282 Infectology center of Latvia. 2010a. HIV statistics. URL:

$283 \quad$ http://www.lic.gov.lv/index.php?p=7793\&pp=10879\&lang=258

284 Infectology center of Latvia. 2010b. HIV therapy. URL:

285 http://infectology.lv/index.php?p=5327\&lang=258

286 Jakobsen MR, Tolstrup M, Sogaard OS, Jorgensen LB, Gorry PR, Laursen A, Ostergaard L. 2010.

287 Transmission of HIV-1 drug-resistant variants: prevalence and effect on treatment 288 outcome. Clin Infect Dis 50(4):566-573.

289 Johnson VA, Brun-Vezinet F, Clotet B, Gunthard HF, Kuritzkes DR, Pillay D, Schapiro JM, 290 Richman DD. 2009. Update of the drug resistance mutations in HIV-1: December 2009. 291 Top HIV Med 17(5):138-145.

292 Kolupajeva T, Aldins P, Guseva L, Dusacka D, Sondore V, Viksna L, Rozentale B. 2008. HIV 293 drug resistance tendencies in Latvia. Cent Eur J Public Health 16(3):138-140.

294 Leigh Brown AJ, Frost SD, Mathews WC, Dawson K, Hellmann NS, Daar ES, Richman DD, 295 Little SJ. 2003. Transmission fitness of drug-resistant human immunodeficiency virus 296 and the prevalence of resistance in the antiretroviral-treated population. J Infect Dis 297 187(4):683-686.

298 Lindstrom A, Albert J. 2003. A simple and sensitive 'in-house' method for determining genotypic 299 drug resistance in HIV-1. J Virol Methods 107(1):45-51.

300 Lindstrom A, Ohlis A, Huigen M, Nijhuis M, Berglund T, Bratt G, Sandstrom E, Albert J. 2006. 301 HIV-1 transmission cluster with M41L 'singleton' mutation and decreased transmission of 302 resistance in newly diagnosed Swedish homosexual men. Antivir Ther 11(8):1031-1039. 303 Lindström A, Albert J. 2003. Corrigendum to "A simple and sensitive 'in-house' method for 304 determining genotypic drug resistance in HIV-1" [J. Virol. Methods 107 (2003) 45-51]. J $305 \quad$ Virol Methods 112:165. 
306 Little SJ, Holte S, Routy JP, Daar ES, Markowitz M, Collier AC, Koup RA, Mellors JW, Connick 307 E, Conway B, Kilby M, Wang L, Whitcomb JM, Hellmann NS, Richman DD. 2002. 308 Antiretroviral-drug resistance among patients recently infected with HIV. N Engl J Med $309347(6): 385-394$.

310 Liu TF, Shafer RW. 2006. Web resources for HIV type 1 genotypic-resistance test interpretation. $311 \quad$ Clin Infect Dis 42(11):1608-1618.

312 Marks AJ, Pillay D, McLean AR. 2010. The effect of intrinsic stochasticity on transmitted HIV 313 drug resistance patterns. J Theor Biol 262(1):1-13.

314 Murillo W, de Rivera IL, Parham L, Jovel E, Palou E, Karlsson AC, Albert J. 2010. Prevalence of 315 drug resistance and importance of viral load measurements in Honduran HIV-infected 316 patients failing antiretroviral treatment. HIV Med 11(2):95-103.

317 Myatt M, Bennett DE. 2008. A novel sequential sampling technique for the surveillance of 318 transmitted HIV drug resistance by cross-sectional survey for use in low resource 319 settings. Antivir Ther 13 Suppl 2:37-48.

320 Pandit A, Mackay WG, Steel C, van Loon AM, Schuurman R. 2008. HIV-1 drug resistance 321 genotyping quality assessment: results of the ENVA7 Genotyping Proficiency 322 Programme. J Clin Virol 43(4):401-406.

323 Pandrea I, Descamps D, Collin G, Robertson DL, Damond F, Dimitrienco V, Gheorghita S, Pecec 324 M, Simon F, Brun-Vezinet F, Apetrei C. 2001. HIV type 1 genetic diversity and 325 genotypic drug susceptibility in the Republic of Moldova. AIDS Res Hum Retroviruses 326 17(13):1297-1304.

327 Payne BA, Nsutebu EF, Hunter ER, Olarinde O, Collini P, Dunbar JA, Basta MS, Elston JW, 328 Schmid ML, Thaker H, Chadwick DR. 2008. Low prevalence of transmitted antiretroviral 329 drug resistance in a large UK HIV-1 cohort. J Antimicrob Chemother 62(3):464-468. 
330 Poggensee G, Kucherer C, Werning J, Somogyi S, Bieniek B, Dupke S, Jessen H, Hamouda O. 331 2007. Impact of transmission of drug-resistant HIV on the course of infection and the

Rumyantseva OA, Olkhovskiy IA, Malysheva MA, Ruzaeva LA, Vasiliev AV, Kazennova EV, Bobkova MR, Lukashov VV. 2009. Epidemiological networks and drug resistance of HIV type 1 in Krasnoyarsk region, Russia. AIDS Res Hum Retroviruses 25(9):931-936.

Santoro MM, Ciccozzi M, Alteri C, Montieri S, Alexiev I, Dimova I, Ceccherini-Silberstein F, Beshkov D, Rezza G, Perno CF. 2008. Characterization of drug-resistance mutations in HIV type 1 isolates from drug-naive and ARV-treated patients in Bulgaria. AIDS Res Hum Retroviruses 24(9):1133-1138.

Shet A, Berry L, Mohri H, Mehandru S, Chung C, Kim A, Jean-Pierre P, Hogan C, Simon V, Boden D, Markowitz M. 2006. Tracking the prevalence of transmitted antiretroviral drugresistant HIV-1: a decade of experience. J Acquir Immune Defic Syndr 41(4):439-446.

Stanczak GP, Stanczak JJ, Firlag-Burkacka E, Wiercinska-Drapalo A, Leszczyszyn-Pynkad M, Jablonowska E, Malolepsza E, Horban A. 2007. Transmission of HIV-1 drug resistance among newly diagnosed patients in Poland. Przegl Epidemiol 61(1):29-34.

Sukhanova AL, Bogoslovskaia EV, Kruglova AI, Bashkirova LI, Tsyganova GM, Shipulin GA, Kazennova EV, Alikina IuI, Zverev SI, Grishechkin AE, Pokrovskii VV, Bobkova MR, Bobkov AF. 2005. Protease and reverse transcriptase genetic polymorphism in HIV type 1 subtype A variants predominating in CIS countries. Mol Biol (Mosk) 39:1063-1071. 
355 Tamura K, Dudley J, Nei M, Kumar S. 2007. MEGA4: Molecular Evolutionary Genetics Analysis 356 (MEGA) software version 4.0. Mol Biol Evol 24(8):1596-1599.

357 The SPREAD Programme. 2008. Transmission of drug-resistant HIV-1 in Europe remains limited $358 \quad$ to single classes. AIDS 22(5):625-635.

359 UK collaborative group on HIV drug resistance, UK collaborative HIV cohort study, UK register 360 of HIV seroconverters. 2007. Evidence of a decline in transmitted HIV-1 drug resistance 361 in the United Kingdom. AIDS 21(8):1035-1039.

362 Van Laethem K, De Luca A, Antinori A, Cingolani A, Perna CF, Vandamme AM. 2002. A 363 genotypic drug resistance interpretation algorithm that significantly predicts therapy 364 response in HIV-1-infected patients. Antivir Ther 7(2):123-129.

365 Vazquez de Parga E, Rakhmanova A, Perez-Alvarez L, Vinogradova A, Delgado E, Thomson 366 MM, Casado G, Sierra M, Munoz M, Carmona R, Vega Y, Contreras G, Medrano L, 367 Osmanov S, Najera R. 2005. Analysis of drug resistance-associated mutations in 368 treatment-naive individuals infected with different genetic forms of HIV-1 circulating in 369 countries of the former Soviet Union. J Med Virol 77(3):337-344.

370 Weinstock HS, Zaidi I, Heneine W, Bennett D, Garcia-Lerma JG, Douglas JM, Jr., LaLota M, 371 Dickinson G, Schwarcz S, Torian L, Wendell D, Paul S, Goza GA, Ruiz J, Boyett B, 372 Kaplan JE. 2004. The epidemiology of antiretroviral drug resistance among drug-naive 373 HIV-1-infected persons in 10 US cities. J Infect Dis 189(12):2174-2180.

374 Vercauteren J, Wensing AM, van de Vijver DA, Albert J, Balotta C, Hamouda O, Kucherer C, 375 Struck D, Schmit JC, Asjo B, Bruckova M, Camacho RJ, Clotet B, Coughlan S, 376 Grossman Z, Horban A, Korn K, Kostrikis L, Nielsen C, Paraskevis D, Poljak M, 377 Puchhammer-Stockl E, Riva C, Ruiz L, Salminen M, Schuurman R, Sonnerborg A, 378 Stanekova D, Stanojevic M, Vandamme AM, Boucher CA. 2009. Transmission of drugresistant HIV-1 is stabilizing in Europe. J Infect Dis 200(10):1503-1508. 
380 Yerly S, Junier T, Gayet-Ageron A, Amari EB, von Wyl V, Gunthard HF, Hirschel B, Zdobnov E, 381 Kaiser L. 2009. The impact of transmission clusters on primary drug resistance in newly 382 diagnosed HIV-1 infection. AIDS 23(11):1415-1423.

383 Yerly S, von Wyl V, Ledergerber B, Boni J, Schupbach J, Burgisser P, Klimkait T, Rickenbach 384 M, Kaiser L, Gunthard HF, Perrin L. 2007. Transmission of HIV-1 drug resistance in 385 Switzerland: a 10-year molecular epidemiology survey. AIDS 21(16):2223-2229. 
1 Table 1. Characteristics of 117 study subjects diagnosed and sampled during 2005 and 2006

\begin{tabular}{|c|c|c|c|}
\hline Characteristics & Study subjects & $\begin{array}{c}\text { No. of diagnosed } \\
\text { patients in 2005-2006 }\end{array}$ & Coverage $(\%)$ \\
\hline Patients & 117 & 598 & 20 \\
\hline $\begin{array}{l}\text { Sex }[\mathrm{n}(\%)] \\
\text { Male } \\
\text { Female } \\
\text { Unknown }\end{array}$ & $\begin{aligned} 69 & (59) \\
45 & (38.5) \\
3 & (2.5)\end{aligned}$ & $\begin{array}{l}380(64) \\
218(36)\end{array}$ & $\begin{array}{l}18 \\
21\end{array}$ \\
\hline $\begin{array}{l}\text { Age (years) } \\
\text { Median (range) }\end{array}$ & $29(17-69)$ & $29(0-69)$ & \\
\hline $\begin{array}{l}\text { Route of transmission [n (\%) } \\
\text { Heterosexual } \\
\text { Intravenous drug use } \\
\text { Homosexual } \\
\text { Mother-to-child } \\
\text { Unknown }\end{array}$ & $\begin{aligned} 25 & (21) \\
44 & (38) \\
10 & (8.5) \\
0 & (0) \\
38 & (32.5)\end{aligned}$ & $\begin{aligned} 183 & (31) \\
222 & (37) \\
30 & (5) \\
6 & (1) \\
157 & (26)\end{aligned}$ & $\begin{array}{r}14 \\
20 \\
35 \\
0 \\
24\end{array}$ \\
\hline $\begin{array}{l}\text { Area of residence [n }(\%)] \\
\text { Riga } \\
\text { Other } \\
\text { Unknown }\end{array}$ & $\begin{aligned} 74 & (63) \\
38 & (33) \\
5 & (4)\end{aligned}$ & $\begin{array}{l}476(80) \\
122(20)\end{array}$ & $\begin{array}{l}16 \\
31\end{array}$ \\
\hline $\begin{array}{l}\text { HIV-1 subtype }[\mathrm{n}(\%)] \\
\text { Subtype A1 } \\
\text { Subtype B }\end{array}$ & $\begin{array}{l}98(84) \\
19(16)\end{array}$ & & \\
\hline $\begin{array}{c}\text { Clinical Stage }[\mathrm{n}(\%)] \\
\text { Stage A } \\
\text { Stage B } \\
\text { Stage C } \\
\text { Unknown }\end{array}$ & $\begin{aligned} 92 & (79) \\
5 & (4) \\
15 & (13) \\
5 & (4)\end{aligned}$ & & \\
\hline $\begin{array}{l}\text { CD } 4 \text { counts }(\text { cells } / \mu 1)^{*} \\
\text { Median (range) }\end{array}$ & $388(27-2002)$ & & \\
\hline $\begin{array}{l}\text { Viral load }\left(\log _{10} \text { copies } / \mathrm{ml}\right)^{\#} \\
\text { Median (range) }\end{array}$ & $4.5(3.0-6.9)$ & & \\
\hline
\end{tabular}

$2{ }^{*}$ The data were not available for 5 patients

$3 \quad$ "Not available for 4 patients 


\section{Page 21 of 21}

Journal of Medical Virology

1 Table 2. Characteristics of the four study subjects with indications of transmitted drug resistance (TDR)

\begin{tabular}{|c|c|c|c|c|c|c|c|c|}
\hline \multirow[b]{2}{*}{ Sequence ID } & \multirow[b]{2}{*}{ Gender } & \multirow[b]{2}{*}{ Age } & \multirow[b]{2}{*}{ Transmission route } & \multirow{2}{*}{$\begin{array}{l}\text { Days from diagnosis to } \\
\text { sampling }\end{array}$} & \multirow[b]{2}{*}{ Subtype } & \multicolumn{3}{|c|}{ Mutations indicative of TDR } \\
\hline & & & & & & PI & NRTI & NNRTI \\
\hline S2023 & Female & 23 & Intravenous drug use & 1 & A1 & F53L & & \\
\hline S2025 & Male & 23 & Unknown & 1 & $\mathrm{~A} 1$ & & M41L & \\
\hline S2114 & Male & 37 & Intravenous drug use & 14 & A1 & & & G190A \\
\hline S2264 & Female & 22 & Unknown & 11 & A1 & M46I & & \\
\hline
\end{tabular}

